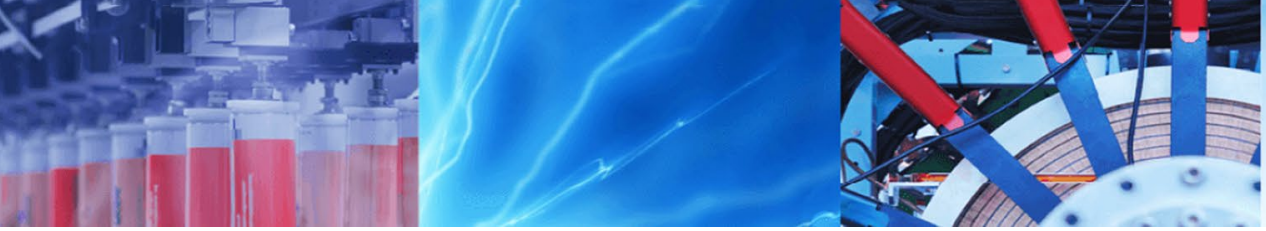

Research Article

\title{
In vitro optimization for enhanced cellulose degrading enzyme from Bacillus licheniformis KY962963 associated with a microalgae Chlorococcum sp. using OVAT and statistical modeling
}

\author{
Freny Shah ${ }^{1} \cdot$ Sandhya Mishra ${ }^{1,2}$
}

Received: 16 May 2020 / Accepted: 13 October 2020 / Published online: 29 October 2020

(c) Springer Nature Switzerland AG 2020

\begin{abstract}
Cellulase has gained interest in researchers due to its great applicability in the field of biotechnology. The Bacillus licheniformis KY962963 used in the study was isolated from Chlorococcum sp. Optimization of various physical parameters like $\mathrm{pH}$, temperature, salinity and effect of co-inducers on the cellulase production (FPase and CMCase) was carried out. In crude enzyme extracts, the selected bacterial strain exhibited higher endoglucanase (CMCase) activity as compared to total cellulase activity (FPase). The highest production of cellulase was obtained with Bacillus licheniformis KY962963 when $1 \%(\mathrm{w} / \mathrm{v})$ cellulose and $0.5 \%(\mathrm{w} / \mathrm{v})$ peptone as co-inducers was used at $37^{\circ} \mathrm{C}, \mathrm{pH} 7.0,72 \mathrm{~h}$ of production time where CMCase activity was found to be of $7.72 \mathrm{IU} / \mathrm{ml}$ and FPase $6.19 \mathrm{IU} / \mathrm{ml}$. The conditions were optimized using OVAT approach which were further validated through statistical modeling. The methods used in this study has established its suitability to optimize cellulase production for its industrial applicability.
\end{abstract}

Keywords Bacillus licheniformis KY962963 · Optimization · RSM · Box-Behnken experimental design

\section{Introduction}

Cellulose is known as one of the natural sources of biopolymer. The lignocellulosic biomass is earth's most dominating renewable resource of agricultural waste materials having a significant potential for biological conversion to high value bioproducts. Cellulose is degraded by the enzyme cellulase frequently produced by cellulolytic microorganisms such as bacteria and fungi. Cellulase has remarkable applicability in numerous industries and hence known as the major part of industrial enzyme. To screen and evaluate nutritional and environmental parameters is the main step for enzyme production. But the production condition for enzymes differs from species to species of different microorganisms used. Moreover, the enzyme activities are altered with varying conditions like substrate specificity, $\mathrm{pH}$, temperature and hence the depiction of enzyme production entail information about optimum $\mathrm{pH}$, stability towards a varying range of temperature and specificity for the substrate [1, 2]. The enzyme manufacturing companies like Novozymes and Genencor have testified significance in emerging more competent and economically affordable enzymes for hydrolysis of cellulosic materials [3]. The disadvantage of these types of enzymes is that they can be optimized for a specific substrate and cannot be useful when the different substrate is used [4]. Production of cellulolytic enzymes by using lignocellulosic material for hydrolysis has shown that the enzyme prepared by this technique can achieve a better standard than commercially prepared enzyme produced by using

$\triangle$ Sandhya Mishra, smishra@csmcri.res.in | 1 Department of Applied Phycology and Biotechnology, CSIR - Central Salt and Marine Chemicals Research Institute, Bhavnagar 364002, India. ${ }^{2}$ Emeritus scientist at Academy of Scientific \& Innovative Research (AcSIR), Academy of Scientific and Innovative Research (AcSIR), CSIR-Central Salt and Marine Chemicals Research Institute, G.B. Marg, Bhavnagar, Gujarat 364002, India. 
a costly substrate like purified cellulose [5]. This approach could be employed for bio-refinery purposes to yield cellulose hydrolyzing enzyme on-site. The major benefit of on-site cellulase production is that it decreases the additional cost of purification and stabilization of the enzyme thus, reducing the overall cost [6].

Cellulases are able to crystalline both the structures of cellulose namely crystalline and para crystalline. To date, numerous bacterial and fungal species are known to produce cellulase [7].

During the last decade, the fungal cellulase was dominatingly used due to its capability to excrete large amount of complex structure of cellulose. Howbeit, in a recent scientific era the concentration is shifted towards the cellulases of bacterial origin. The reason behind this is the capability of bacteria to grow in a harsh environmental conditions and presence of multi-enzyme complexes which tends to bestow enhanced synergy and function [8]. Bacterial domain has acquired advancement of marketable progression to degrade cellulose due to its faster-growing characteristics, diverse genetic variableness, adaptability and highly amended capability to genetic manipulation [9]. However, till the recent years, the study on cellulases derived from bacterial origin was of less importance than the fungal domain as it has a potential to hydrolyze only synthetically available carboxymethyl cellulose [10]. The factors that affect the production of cellulolytic enzymes are inoculum concentration, the value of $\mathrm{pH}$, temperature, the existence of inducers, exposure to air and growth rate.

Further, research revealed commercial worth and industrial applicability of cellulases [11,12]. It has an eclectic variety of usability in a diverse area of the food industry, industries of pulp and paper, medicinal industries, textile sectors, liquor-based matrices, malting and brewing, starch processing, biofuel production and leather/tannery, etc. [1]. To meet the demand of cellulase enzyme for the above-said applications, optimization of physicochemical factors, one variable at a time (OVAT) is frequently used by investigators to find out the finest parameters and the precise effects of variables. However, it is difficult to carry out numerous investigational trials and hence the interface between variables turns out to be problematic to assess and frequently getting unsuccessful results $[13,14]$. To overcome this problem Plackett-Burman design (PBD) is used. Box-Behnken design was further applied to justify the response surface [15].

To optimize several variables for the determination of process conditions that suits the best for enhanced cellulase production, response surface methodology (RSM) is used. This technique works by combination of several experimental designs with interpolation by first-or second-multinomial equations in a consecutive test process [16]. This is now observed that RSM can be used as a conventional statistical approach to design an experiment, to make a model for building construction, evaluation of the effects of multiple factors, to optimize conditions for required responses by reducing the experiment number [17].

This study demonstrates the applicability of RSM to optimize the best conditions for higher cellulase production from Bacillus licheniformis KY962963 and the relation amid the variables that effects the response of the production of cellulase. The present study was focused to optimize various nutritional and process parameters to yield the determined production of cellulase from designated pure culture by keeping in view the above facts about the cellulose hydrolyzing enzyme and its usability in industrial matrices.

\section{Materials and methods}

\subsection{Cellulase production}

The isolated bacterial strain was inoculated in a basal media reported by [18]. After the optimal period of incubation, experimental flasks were harvested. The fermented biomass samples were centrifuged at 10,000 rpm for $15 \mathrm{~min}$ at $20^{\circ} \mathrm{C}$ temperature (in the centrifuge) for removal of the spores and then filtered. The supernatants were carefully collected and stored aseptically under the refrigerated condition to prevent contamination. After filtration, $\sim 20 \mathrm{ml}$ of the crude enzyme was obtained from each flask of the different substrate.

\subsection{Optimization condition for enzyme production using one variable at a time approach (OVAT)}

The effect of different production condition like substrate type, basal medium concentration level, temperature, $\mathrm{pH}$ of the medium, incubation time, carbon sources and nitrogen sources are described below:

\subsubsection{Effect of temperature}

Temperature range $\left(20,25,30,37,40\right.$ and $\left.55^{\circ} \mathrm{C}\right)$, we can get an idea of temperature optima for maximum cellulase production. $0.1 \mathrm{M}$ phosphate buffer of $\mathrm{pH} 7$ is employed as a substrate in this study and it will remain constant for the experiment.

\subsubsection{Effect of $\mathrm{pH}$}

The $\mathrm{pH}$ optima of the cellulase were examined by utilizing a wide range of $\mathrm{pH}(\mathrm{pH} 5-13)$ buffers in an assay reaction mixture. The stability of the cellulase was assessed after preincubating the enzyme in varied buffers ranging from $\mathrm{pH}$ 5-6 (sodium citrate buffer), 6-8 (phosphate 
buffer), 8-10 (glycine-NaOH buffer), $10-11\left(\mathrm{NaHCO}_{3} / \mathrm{NaOH}\right.$ buffer), and 11-13 (KCl/NaOH buffer) for $30 \mathrm{~min}$. Standard assay conditions were followed to determine the residual enzyme activity. A calibrated $\mathrm{pH}$ meter was used.

\subsubsection{Effect of salinity}

A wide range of $\mathrm{NaCl}$ concentration i.e., $0.5-12.5 \%$ w/v was mixed with the production medium to find out the best salinity concentration for maximum cellulase production. The procedure was carried out at an optimized $\mathrm{pH}$ and temperature for $72 \mathrm{~h}$.

\subsubsection{Effect of the incubation period}

The consequence of the incubation period was detected on the activity of the cellulolytic enzyme acquired by BacilIus licheniformis KY962963. The optimized and inoculated production media was incubated at $37^{\circ} \mathrm{C}$ for various time interludes ranging from 24 to $144 \mathrm{~h}$ at an interval of $24 \mathrm{~h}$.

\subsubsection{Effect of CMC concentration}

To optimize the concentration of CMC for higher cellulase production, varied concentrations of CMC were added in the production medium ranging from $0.5 \%$ to $2.5 \% \mathrm{w} / \mathrm{v}$ at an interval of $0.5 \%$. Subsequently, inoculation with bacterial strain was done followed by incubation at $37^{\circ} \mathrm{C}$ for $72 \mathrm{~h}$ at $120 \mathrm{rpm}$.

\subsubsection{Effect of inoculum concentration}

The outcome of varied concentrations of inocula used $(0.5 \% 1 \%, 2 \%, 3 \%, 4 \%, v / v)$ of Bacillus licheniformis KY962963 was observed on the activity of cellulase after $72 \mathrm{~h}$ of incubation period at $37^{\circ} \mathrm{C}$

\subsubsection{Effect of carbon source}

The various sources of carbon viz. maltose, fructose, sucrose, lactose, glucose, and xylose were added ( $1 \% \mathrm{w} / \mathrm{v})$ in production media under optimum conditions to evaluate the best co-substrate for cellulase.

\subsubsection{Effect of nitrogen source}

The various nitrogen sources like peptone, ammonium sulfate, yeast extract, ammonium chloride, sodium nitrate and urea in the production medium to evaluate the finest nitrogen source for the cellulolytic enzyme production. The production procedure was carried out at an optimum temperature for $72 \mathrm{~h}$.

\subsection{Statistical designs}

\subsubsection{Box-Behnken design}

Table 3 epitomizes the model design of a standard 15 order of run. Applying this statistical model, variables having greatest levels of confidence were coded as +1 , 0 and -1 for high, central and low values, respectively. To predict the point of optimum condition optimal, a second-order multinomial function was adapted to relate the association amid the response by means of the cellulase production and independent variables.

The prototype established as a function of a response of the several variables for the higher cellulase production was a second-order polynomial which can be described as follows.

$\mathrm{Y}=\beta_{0}+\sum \beta_{\mathrm{i}} \mathrm{X}_{\mathrm{i}}+\sum \beta_{\mathrm{ii}} \mathrm{X}_{\mathrm{i}}^{2}+\sum \beta_{\mathrm{ij}} \mathrm{X}_{\mathrm{i}} \mathrm{X}_{\mathrm{j}}$

To check the response when using three variables, the followed equation can be applied.

$$
\begin{aligned}
\mathrm{Y}= & \beta_{0}+\beta_{1} \mathrm{X}_{1}+\beta_{2} \mathrm{X}_{2}+\beta_{3} \mathrm{X}_{3}+\beta_{11} \mathrm{X}_{1}^{2}+\beta_{22} \mathrm{X}_{2}^{2} \\
& +\beta_{33} \mathrm{X}_{3}^{2}+\beta_{12} \mathrm{X}_{1} \mathrm{X}_{2}+\beta_{13} \mathrm{X}_{1} \mathrm{X}_{2}+\beta_{23} \mathrm{X}_{2} \mathrm{X}_{3}
\end{aligned}
$$

where $Y$ is the predicted value of response, $\beta_{0}$ is the model constant; $X_{1}, X_{2}$, and $X_{3}$ are independent variables; $\beta_{1}, \beta_{2}$, and $\beta_{3}$ are linear coefficients; The variables selected for optimization, i.e., $\mathrm{pH}$, incubation temperature, and the salinity, were coded as $X 1, X 2$, and $X 3$, respectively. The experiments designed for statistical optimization were performed in triplicates. Minitab 18 was used for the regression investigation of the acquired experimental data. The fitting eminence of the polynomial model equation was expressed by the coefficient of determination $R^{2}$.

\section{Biochemical studies}

\subsection{Evaluation of cellulase activity}

The assay performed was followed by the method of Ghose [19]. The FPase activity was used for the determination of total cellulase activity. CMC has most commonly been used for the assay of endoglucanase activity; cellobiase is assayed via cellobiose hydrolysis and the release of reducing sugars (monosaccharides).

\subsubsection{Total cellulase activity (EC:3.2.1.4)}

\section{Reagents:}


- Filter paper strip,

- 3,5-Dinitrosalicylic acid reagent

- Sodium phosphate buffer $0.05 \mathrm{M}, \mathrm{pH} 7.0$.

Substrate: Whatman No. 1 filter paper strip.

Procedure: Whatman No. 1 filter paper strips $1.0 \times 6.0 \mathrm{~cm}$ was inserted into a test tube containing $1.0 \mathrm{ml}$ sodium phosphate buffer of $0.05 \mathrm{M}$ concentration having a pH 7.0 and added $0.5 \mathrm{ml}$ of crude enzyme. Two blanks were similarly prepared wherein one did not contain the enzyme and in the other enzyme was added after the termination of the reaction. All the tubes were incubated in a thermostatically regulated water bath at $50^{\circ} \mathrm{C}$ for $1 \mathrm{~h}$. Added $3.0 \mathrm{ml}$ DNS reagent to terminate the reaction. The tubes were boiled for $5 \mathrm{~min}$ on a boiling water bath. Cooled immediately, added $20 \mathrm{ml}$ of DW and mixed well. The OD was read at $540 \mathrm{~nm}$ against blank prepared without enzyme. Glucose released during the assay was calculated from a calibration graph of standard glucose.

\subsubsection{Endoglucanase activity (EC:3.2.1.4)}

\section{Reagents:}

- Carboxymethyl cellulose

- 3,5-Dinitrosalicylic acid reagent

- Sodium phosphate buffer $0.05 \mathrm{M}, \mathrm{pH}$ 7.0.

Substrate: $2 \%$ Carboxymethyl cellulose CMC was prepared in sodium phosphate buffer ( $\mathrm{pH} 7.0)$.

Procedure: To $0.5 \mathrm{ml} \mathrm{CMC}$ was added $0.5 \mathrm{ml}$ crude enzyme. A blank solution containing $1.0 \mathrm{ml} \mathrm{CMC}$ was also prepared. The tubes were incubated $50^{\circ} \mathrm{C}$ for $30 \mathrm{~min}$ in a water bath. The reaction was terminated by adding $3 \mathrm{ml}$ of DNS after reaction termination $0.5 \mathrm{ml}$ citrate buffer added in a blank tube and $0.5 \mathrm{ml}$ crude enzyme was added in the enzyme blank tube. The all three assayed mediums were boiled for $5 \mathrm{~min}$ and tubes cooled immediately. The $20 \mathrm{ml} \mathrm{DW}$ was added in each test tube, mixed well. The absorbance was read at $540 \mathrm{~nm}$ and followed the above-mentioned procedure then calculated the CMCase activity by the following equation.

\section{Results and discussion}

\subsection{Optimization of culture conditions using OVAT}

One unit of cellulase activity can be expressed as the amount of cellulase produce $1 \mathrm{mmol}$ of glucose per minute at $\mathrm{pH} 7.0$ and $37{ }^{\circ} \mathrm{C}$ [20]. The most promising strain for higher cellulase production was identified as Bacillus licheniformis KY962963. The composition of media and culture conditions such as temperature, $\mathrm{pH}$, salinity, substrate, carbon and nitrogen source, size of inocula, and incubation period were subsequently optimized for the thoroughgoing cellulase production step-by-step. The procedure of media optimization is a significant parameter for the buildout process of fermentation technology to make the process economically green. For the cost reduction of the enzyme, it is important to use cost-effective media components.

\subsection{Effect of temperature}

Temperature is a critical part of the growth and physiology of microbial species and its enzymatic activity. The best total cellulase (FPase) and endoglucanase (CMCase) activity of 4.51 and $4.96 \mathrm{IU} / \mathrm{ml}$, respectively, was detected at $37^{\circ} \mathrm{C}$, which was somewhat abridged to 3.76 and 4.12 $\mathrm{IU} / \mathrm{ml}$, respectively, at $40^{\circ} \mathrm{C}$ (Fig. 1).

The diminution of enzymatic activity was observed with the temperature range higher than the optimal values. This results in subsequent loss of enzymatic activity, as enzymes tend to be denatured at a higher temperature. Hence, reduced enzyme activity was detected above $45^{\circ} \mathrm{C}$. Similarly, maximum cellulose hydrolyzing enzyme production of $0.5851 \pm 0.006 \mathrm{IU} / \mathrm{ml}$ was attained at $37^{\circ} \mathrm{C}$ from Bacillus pumilus EWBCM1 [21].

\subsection{Effect of $\mathrm{pH}$}

The media for the production of cellulase having varied $\mathrm{pH}(5,6,7,8,9,10,11,12$, and 13) was utilized. The experiment suggests the optimum $\mathrm{pH}$ value for higher cellulolytic enzyme production was $\mathrm{pH} 7$ with showed maximum FPase activity of $4.92 \mathrm{IU} / \mathrm{ml}$ and CMCase activity of $5.69 \mathrm{lU} /$ $\mathrm{ml}$ (Fig. 2).

Changes in $\mathrm{pH}$ may lead to the alteration in the active site of the enzyme. Cellulomonas sp. YJ5 isolated by [22] showed its optimum activity at a pH of 7 and stability over

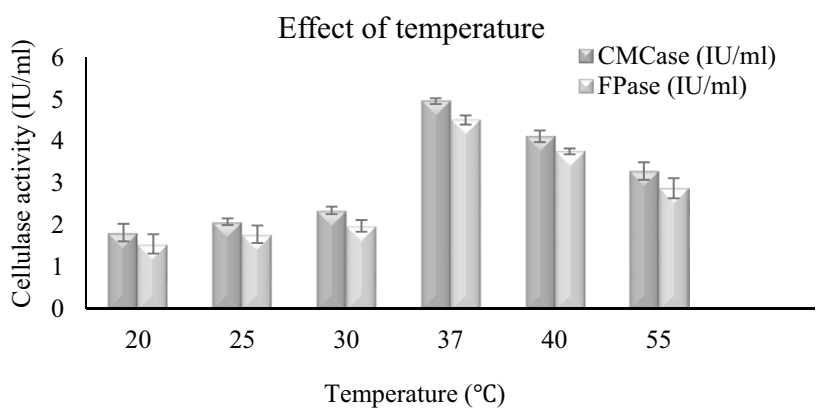

Fig. 1 Effect of temperature on cellulase production 


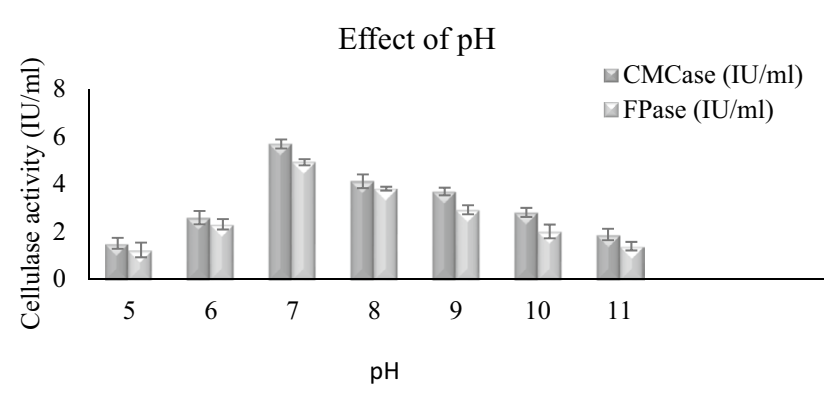

Fig. 2 Effect of $\mathrm{pH}$ on cellulase production

a wide range of $\mathrm{pH} 7.5-10.5$. The previous report suggests that the $\mathrm{pH}$ range of 7-7.5 was found to be optimum for higher production of a cellulolytic enzyme using Bacillus subtilis and Bacillus circulans [23]. Bacillus sp. 8 and Bacillus sp. 17 showed the maximum cellulase production at $\mathrm{pH} 7$ [24]. The best CMCase activity of $0.29 \mathrm{IU} / \mathrm{mL}$ was testified in a study using Bacillus sp. at pH 7 [25].

\subsection{Effect of salinity}

The production medium was augmented with various $\mathrm{NaCl}$ concentrations ranging from $0.5 \% \mathrm{w} / \mathrm{v}$ to $12.5 \% \mathrm{w} / \mathrm{v}$ to check its upshot. The optimum salt concentration for cellulase production was found to be $3.5 \%$ with maximum FPase and CMCase activity of $3.91 \mathrm{IU} / \mathrm{ml}$ and $4.99 \mathrm{IU} / \mathrm{ml}$ (Fig. 3).

It has been suggested that high salt concentration can encumber the activity of an enzyme of mesophilic proteins by a disruption in a hydrogen bond. High salinity may result in the protein's shell deprivation by disturbing hydrophobic interactions [26-30]. Previous studies suggest that the presence of salt can create high ionic strength and low water activity in the surrounding environment [26-31]. Characteristic studies suggest that the cytoplasm of halophilic microorganisms have $>3 \mathrm{M}$ salt concentration. Consequently, they harbor an exceptional mechanism to strive for water with salt. Proteins of

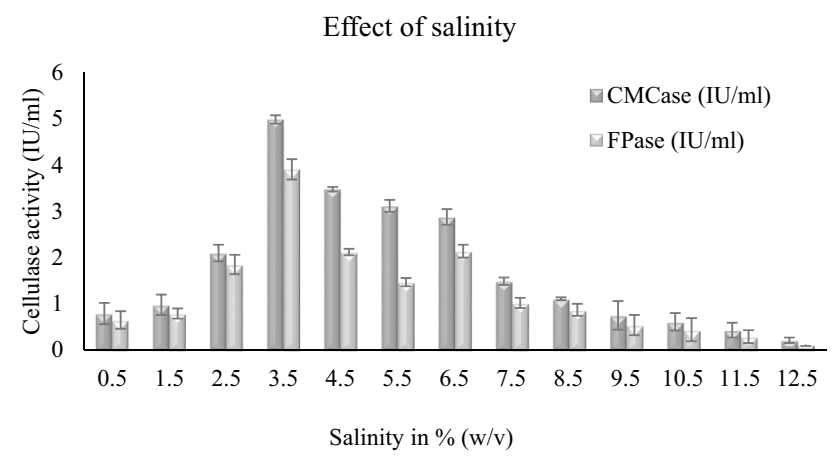

Fig. 3 Effect of salinity on cellulase production halophilic microorganism comprise an enormous acidic amino acid which is negatively charged and only a few basic amino acids on their surface. They also possess a low content of hydrophobic amino acid [32-35]. Previous research mentioned that negatively charged amino acids might maintain the solubility of a protein in a highly saline solution. The mechanism responsible for this phenomenon is either a formation of a network of hydrated cations or prevention from protein aggregation via electrostatic repulsion at the surface of protein [36-40]. Due to these reasons, cellulase produced from marine Bacillus licheniformis KY962963 can retain its activity up to $6.5 \% \mathrm{NaCl}$ concentration and proves its origin from a marine source.

\subsection{Effect of the incubation period}

To optimized the incubation period, production media was incubated at varied time intervals ranging from 24 to $144 \mathrm{~h}$ after inoculation with Bacillus licheniformis KY962963. The optimum period of incubation for the production of cellulase was observed after $72 \mathrm{~h}$ of incubation with FPase activity $(6.19 \mathrm{IU} / \mathrm{ml})$ and CMCase activity $(7.72 \mathrm{lU} / \mathrm{ml})$ (Fig. 4).

The incubation period is an important parameter of the optimization process for higher cellulase yield. A slight reduction in the activity of cellulase was observed after $72 \mathrm{~h}$. The activity of cellulase markedly decreased after $96 \mathrm{~h}$ due to exhaustion of nutrients or accrual of other toxic byproducts in the production medium which resulted in a reduction of cellulase activity. The report suggests that maximum CMCase and FPase activity of $7.82 \mathrm{IU} /$ $\mathrm{mL}$ and $6.84 \mathrm{IU} / \mathrm{mL}$ was observed after $96 \mathrm{~h}$ of incubation while using Bacillus sp. Y3 [41].

\subsection{Effect of CMC concentration}

To estimate the effect of various CMC concentration on the production of cellulase by Bacillus licheniformis KY962963, various CMC concentration $(0.5 \%, 1 \%, 1.5 \%$, $2 \%, 2.5 \%, \mathrm{w} / \mathrm{v}$ ) were supplemented to the production

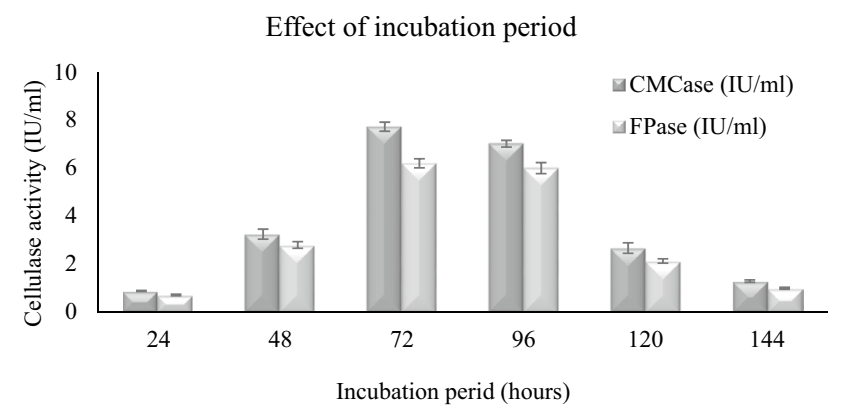

Fig. 4 Effect of incubation period on cellulase production 
media. The maximum FPase and CMCase activity of 3.81 and $4.69 \mathrm{IU} / \mathrm{ml}$, respectively, was detected with $1 \%(\mathrm{w} / \mathrm{v})$ CMC (Fig. 5).

Carboxymethylcellulose (CMC), is a water-soluble derivative of cellulose. It is a suitable compound to detect the production of cellulase because it is easily degradable by micro-organisms. As the result suggest that $1 \%$ CMC concentration is optimum for higher cellulase production, the previous report also confirmed the maximum enzyme activity of $3.028 \mu \mathrm{g} / \mathrm{mg} / \mathrm{min}$ was attained when using CMC as a source of carbon from Bacillus sp. [42]. Nasr et al. [24] also found similar results using Bacillus sp. Bacillus sp. BSS3 was found to produce a high cellulase i.e., $104.68 \mathrm{U} / \mathrm{mL}$ in the previously optimized production media supplemented with $1 \%(\mathrm{w} / \mathrm{v})$ $\mathrm{CMC}$ at $37^{\circ} \mathrm{C}$ and $150 \mathrm{rpm}$ [43]. In another study, the best cellulase production by means of yield has beenrecorded when using Bacillus amyloliquefaciens SS35 by supplemented the production medium with $1.9 \%(\mathrm{w} / \mathrm{v})$ CMC.

\subsection{Effect of inoculum concentration}

The effect of different inoculum concentrations of Bacillus licheniformis KY962963 ranging from $0.5 \%$ to $4 \% \mathrm{v} / \mathrm{v}$ at an interval of $1 \%$ was observed. The optimal concentration of inoculum was noted at $2 \%(\mathrm{v} / \mathrm{v})$ by showing maximum FPase and CMCase activity of 4.98 and $5.41 \mathrm{lU} /$ $\mathrm{ml}$, respectively (Fig. 6).

The cellulase activity was suddenly decreased because the growth of the organism was declined because of the upsurge in the struggle for space and nutrients among cells when the inoculum concentration above the optimum level increased. These may lead to the loss of enzyme activity as it affects the length of the stationary phase. Comparable data for maximum cellulase production with $2 \%(\mathrm{v} / \mathrm{v})$ inoculum concentration was also reported [44]. In another study Bacillus pumilus of $2 \%(\mathrm{v} / \mathrm{v})$ concentration was detected to be optimum for higher cellulase production [45].

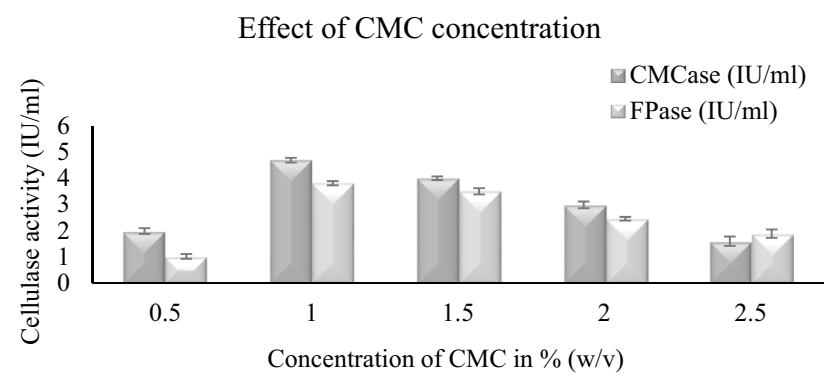

Fig. 5 Effect of CMC concentration on cellulase production
Effect of inoculum concentration

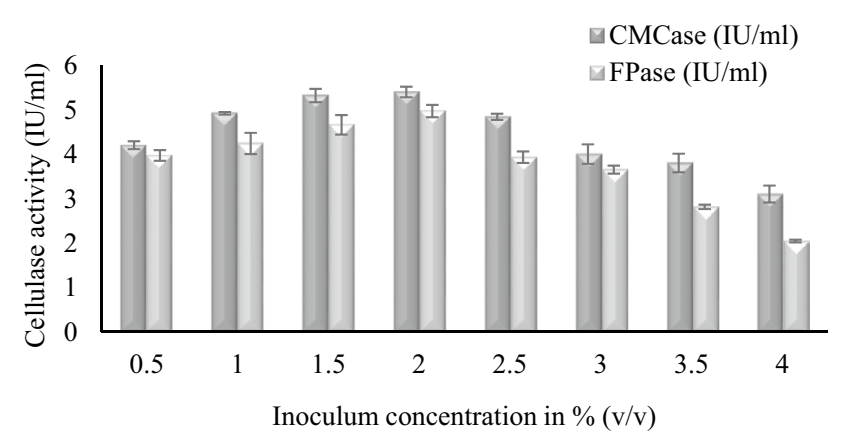

Fig. 6 Effect of inoculum concentration on cellulase production

\subsection{Effect of carbon source}

Different carbon sources viz. maltose, fructose, sucrose, lactose, glucose, and xylose were studied by adding them to the growth media. The concentration of these carbon sources was kept $1 \% \mathrm{v} / \mathrm{w}$. Results obtained showed that glucose could be the appropriate carbon source for the highest cellulase production when compared to others. The best FPase and CMCase activity of $3.43 \mathrm{IU} / \mathrm{ml}$ and $4.52 \mathrm{IU} / \mathrm{ml}$ respectively were found in the media containing glucose. Lactose (FPase $2.99 \mathrm{IU} /$ $\mathrm{ml}$, CMCase $4.12 \mathrm{IU} / \mathrm{ml}$ ) and maltose (FPase $2.88 \mathrm{IU} / \mathrm{ml}$, CMCase $3.98 \mathrm{lU} / \mathrm{ml}$ ) also showed high cellulase production (Fig. 7).

The previous report studied that [46] in the presence of D-xylose, the maximum cellulase production was obtained while, [47] reported deduction in cellulase activity when using xylose as it cannot metabolize well bacterial strains that unveiled higher cellulase production in the media containing glucose [48].

\subsection{Effect of nitrogen sources}

The effect of varied nitrogen sources like peptone, yeast extract, ammonium sulfate, ammonium chloride, sodium nitrate and urea, each with $0.5 \%(\mathrm{w} / \mathrm{v})$ was detected.

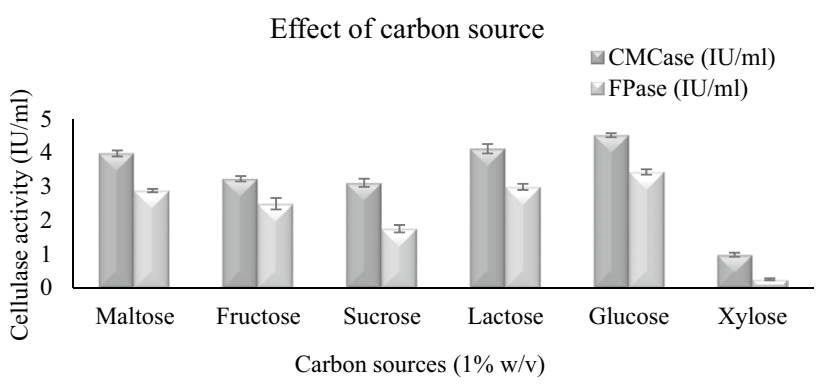

Fig. 7 Effect of carbon sources on cellulase production 
The best FPase and CMCase activity of $4.72 \mathrm{IU} / \mathrm{ml}$ and $5.23 \mathrm{IU} / \mathrm{ml}$, respectively, when using peptone as a nitrogen source (Fig. 8).

Different carbohydrate and nitrogen sources can repress the enzyme production by reducing the activity of an enzyme. Nitrogen is known as the chief cell proteins and enhancement in the cellulolytic activity by ammonium sulfate salt might occur as this salt can directly be entered in the synthesis of protein. To supplement the external source of nitrogen is essential for the fermentation to utilize soluble carbohydrates effectively. The organic nitrogen sources were found to be more suitable for maximum cellulase production [49].

\subsection{Statistical design}

Physic-chemical parameters such as oxygen levels, $\mathrm{pH}$, water activity, temperature, concentrations of nutrients, and in the production media can significantly affect the growth of microorganism and the formation of product

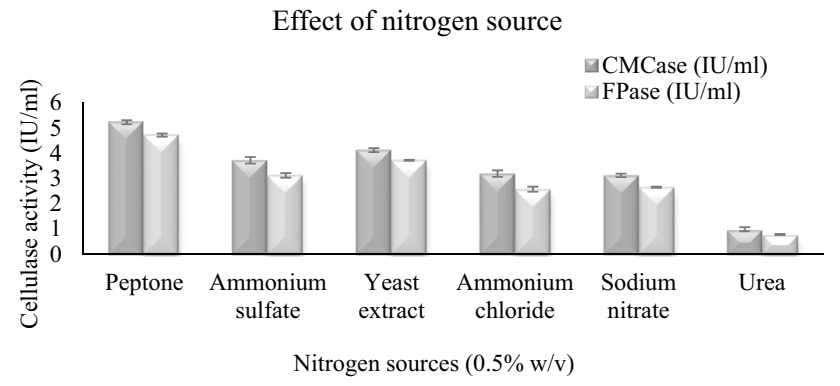

[50] and a careful assortment of these parameters can vividly enhance the cellulase production when SSF performed. The levels of $\mathrm{pH}$, temperature, and concentration of salinity were variegated as designated in the model of the experiment. Optimization using statistical modeling gives a prospect to optimize process levels of variables under any specified condition by demonstrating the correlation between the predicted values and the variables.

$$
\begin{aligned}
Y= & -1128+58.68 X i+49.15 X i i+13.78 X i i i-2.770 X i^{2} \\
& -0.6113 X^{2} i^{2}-0.5719 X_{i i i}^{2}-0.493 X i X i i \\
& -0.514 X_{\text {Xiii }}-0.1681 X_{i i X i i i}
\end{aligned}
$$

The equation was applied to analyze the response prediction mentioned in Table 1. Comparative analysis of a predicted value with the experimental value proves that acquired data are in practical agreement.

The maximum response $(7.81 \mathrm{IU} / \mathrm{ml})$ was obtained in run number 8 , and in general, all the runs with central levels of tested variables showed maximum yields compared to other combinations. The data was scrutinized by multiple regression analysis, and the regression coefficients were determined (Table 2).

Where, $\mathrm{X} 1=\mathrm{pH}$ of the production medium

$\mathrm{X} 2=$ Incubation temperature $\left({ }^{\circ} \mathrm{C}\right)$

$\mathrm{X} 3=$ Salinity of the production medium (\%)

Appropriateness of the design was confirmed using Fisher's test for the ANOVA (analysis of variance) using Minitab 18. The importance of explicit factors can be evaluated by their P-values (Table 3 ), the more momentous relations has a less $P$-value.

Fig. 8 Effect of nitrogen sources on cellulase production

Table 1 Box-Behnken experiment design matrix with observed and predicted responses for different trials

\begin{tabular}{llllll}
\hline Run order & $\mathrm{pH}$ & $\begin{array}{l}\text { Temperature } \\
\left({ }^{\circ} \mathrm{C}\right)\end{array}$ & Salinity (\%) & $\begin{array}{l}\text { Cellulase (IU/ml) } \\
\text { observed }\end{array}$ & $\begin{array}{l}\text { Cellulase (IU/ml) } \\
\text { predicted }\end{array}$ \\
\hline 1 & 7 & 35 & 1.5 & 2.81 & 2.66 \\
2 & 7 & 39 & 1.5 & 4.21 & 3.54 \\
3 & 6 & 39 & 3.5 & 3.12 & 3.41 \\
4 & 6 & 37 & 5.5 & 4.2 & 3.76 \\
5 & 8 & 35 & 3.5 & 3.94 & 3.65 \\
6 & 7 & 39 & 5.5 & 1.9 & 2.04 \\
7 & 8 & 37 & 1.5 & 3.26 & 3.69 \\
8 & 7 & 37 & 3.5 & 7.81 & 7.76 \\
9 & 6 & 35 & 3.5 & 2.15 & 1.91 \\
10 & 8 & 37 & 5.5 & 1.86 & 7.48 \\
11 & 7 & 37 & 3.5 & 8.21 & 1.86 \\
12 & 6 & 37 & 1.5 & 1.49 & 7.76 \\
13 & 7 & 37 & 3.5 & 7.26 & 3.85 \\
14 & 7 & 35 & 5.5 & 3.19 & 1.2 \\
15 & 8 & 39 & 3.5 & 0.97 & \\
\hline
\end{tabular}


Table 2 Coefficients of the response function to predict cellulase production by regression analysis

\begin{tabular}{lll}
\hline Factor & Coded coefficient & $\begin{array}{l}\text { Coef- } \\
\text { ficient } \\
\text { estimate }\end{array}$ \\
\hline Intercept & $\beta_{0}$ & 23.21 \\
$X_{1}$ & $\beta_{1}$ & 1.29 \\
$X_{2}$ & $\beta_{2}$ & 0.12 \\
$X_{3}$ & $\beta_{3}$ & 1.31 \\
$X_{1}{ }^{2}$ & $\beta_{11}$ & -3.15 \\
$X_{2}{ }^{2}$ & $\beta_{22}$ & -1.43 \\
$X_{3}{ }^{2}$ & $\beta_{33}$ & 0.67 \\
$X_{1} X_{2}$ & $\beta_{12}$ & -0.14 \\
$X_{1} X_{3}$ & $\beta_{13}$ & 0.52 \\
$X_{2} X_{3}$ & $\beta_{23}$ & -0.04 \\
\hline
\end{tabular}

Table 3 Analysis of variance for the response surface quadratic model

\begin{tabular}{lcclcl}
\hline Source & Sum of square & $\mathrm{dF}$ & Mean square & F value & P value \\
\hline Model & 71.0399 & 9 & 7.8933 & 16.94 & 0.003 \\
$\mathrm{X}_{1}$ & 0.1081 & 1 & 0.1081 & 0.23 & 0.65 \\
$\mathrm{X}_{2}$ & 0.4465 & 1 & 0.4465 & 0.96 & 0.373 \\
$\mathrm{X}_{3}$ & 0.048 & 1 & 0.048 & 0.1 & 0.761 \\
$\mathrm{X}_{1}{ }^{2}$ & 28.3307 & 1 & 28.3307 & 60.82 & 0.001 \\
$\mathrm{X}_{2}{ }^{2}$ & 22.0727 & 1 & 22.0727 & 47.38 & 0.001 \\
$\mathrm{X}_{3}{ }^{2}$ & 19.3206 & 1 & 19.3206 & 41.47 & 0.001 \\
$\mathrm{X}_{1} \mathrm{X}_{2}$ & 3.8809 & 1 & 3.8809 & 8.33 & 0.034 \\
$\mathrm{X}_{1} \mathrm{X}_{3}$ & 4.223 & 1 & 4.223 & 9.07 & 0.03 \\
$\mathrm{X}_{2} \mathrm{X}_{3}$ & 1.809 & 1 & 1.809 & 3.88 & 0.106 \\
Residual & 2.3292 & 5 & 0.4658 & & \\
Lack of fit & 1.8742 & 3 & 0.6247 & 2.75 & 0.278 \\
Pure error & 0.455 & 2 & 0.2275 & & \\
Cor total & 73.3692 & 14 & & & \\
\hline
\end{tabular}

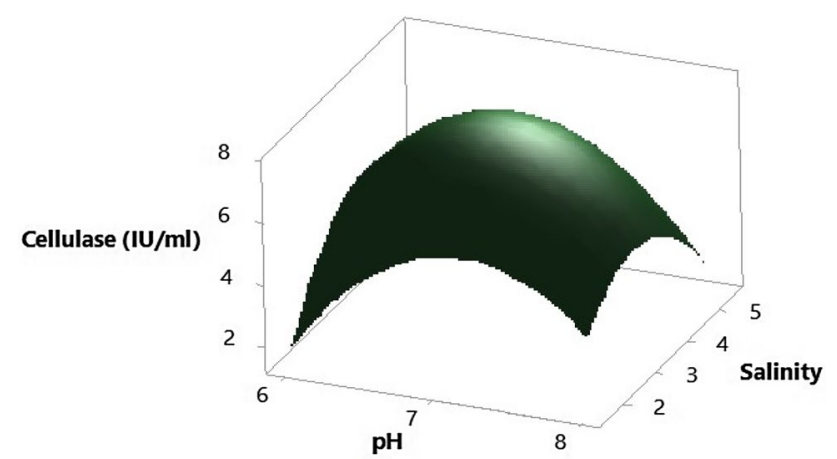

Fig. 9 Three-dimensional response surface plot for the interaction of $\mathrm{pH}$ and salinity

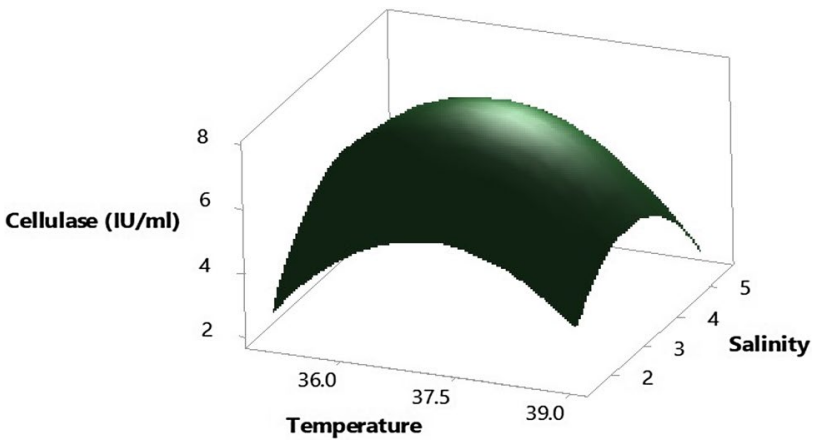

Fig. 10 Three-dimensional response surface plot for the interaction of temperature and salinity

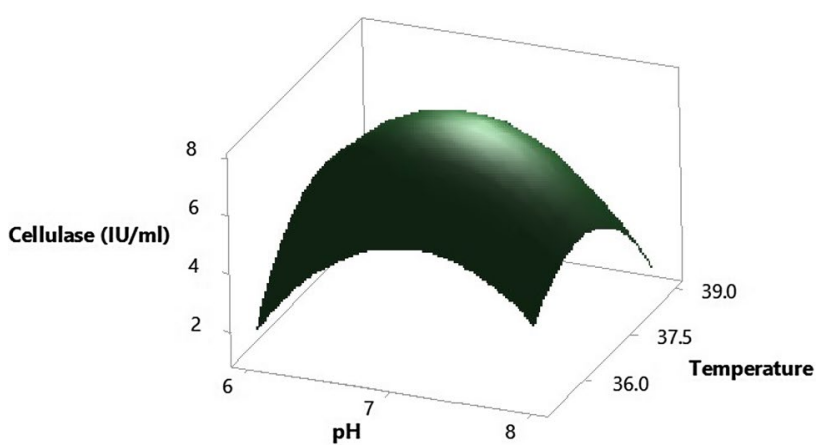

Fig. 11 Three-dimensional response surface plot for the interaction of $\mathrm{pH}$ and temperature

Figures 9,10 , and 11 signifies the response attained for the interaction of examined parameters. The facts obtained in the plots of response specified that the production of cellulase increased at $\mathrm{pH} 7$ and at the salinity concentration of $3.5 \%$. The profiles of contour plots signify the nature and degree of the relatedness (Fig. 9). It has been significantly detected from the figure that there is no significance between the examined parameters.

The optimum temperature and $\mathrm{pH}$ were within these ranges where the maximal activity of $7.76 \mathrm{IU} / \mathrm{ml}$ was predicted by the model. The effects of incubation temperature and salinity are shown in Fig. 10.

It may be detected from the surface contour plot that there is a trivial shift in optimum salinity to the lower merit when temperature is increased. Similarly, the interaction effects plotted for $\mathrm{pH}$ and incubation temperature showed that there are no significant interactions between these variables that affect cellulase production (Fig. 11).

However, this confirmed that the optimal temperature range lied between 36 and $37^{\circ} \mathrm{C}$, and the optimal pH was between 6 and 7 . 


\section{Conclusion}

Above study indicates that Bacillus licheniformis KY962963 is a potential isolate for cellulase production and further hydrolyzing cellulose into fermentable carbohydrates. Here, cellulase production from extremotolerant Bacillus licheniformis KY962963 was optimized and showed significant enhancement in the FPase and CMCase activity in a production media ( $1 \% \mathrm{CMC}, 0.5 \%$ peptone; $\mathrm{pH} 7.0$ ) inoculated with $2 \%(\mathrm{v} / \mathrm{v})$ inoculum incubated at $37^{\circ} \mathrm{C}$ for $72 \mathrm{~h}$ at $120 \mathrm{rpm}$. The current study has demonstrated that CMC along with glucose and peptone encouraged the higher cellulase production using Bacillus licheniformis KY962963 an epiphyte of Chlorococcum sp. Higher production of bacterial cellulase by optimizing several physical parameters leads to its cost reduction increase its applicability in various industries such as laundry, textile, leather, brewery etc.

Acknowledgments The authors like to acknowledge Dr. Amitava Das (Ex-Director), CSIR-CSMCRI and Dr. Arup Ghosh, DC, APB for providing amenities and inspiration. FS is grateful to CSIR-HRDG for providing financial support. FS would like to thank Dr. Sonam Dubey and Mr. Vamsi Bharadwaj for their help to revise manuscript thoroughly and all the lab members to create such a good and lively working environment. This manuscript has been allotted CSIR-CSMCRI registration number 28/2020.

\section{Compliance with ethical standards}

Conflict of interest There is no conflict of interest

Human or animal rights Human or animal rights are not applicable to this study.

\section{References}

1. Bhat MR (2000) Cellulases and related enzymes in biotechnology. Biotechnol Adv 18:355-383

2. Parry NJ, Beever DE, Owen E, Vandnberghe J, Beeumen V, Bhat M (2002) Biochemical characterization and mechanism of action of a thermostable ß-glucosidase purified from Thermoascus aurantiacu. Biochem J 353:117-127

3. Wilson DB (2009) Cellulases and biofuels. Curr Opin Biotech 20:295-299

4. Zhang YHP, Himmel ME, Mielenz JR (2006) Outlook for cellulase improvement: screening and selection strategies. Biotehcnol Adv 24:452-481

5. Roberto IC, Mussatto SI, Rodrigues RCLB (2003) Dilute-acid hydrolysis for optimization of xylose recovery from rice straw in a semi-pilot reactor. Ind Crops Prod 17:171-176

6. Himmel ME, Ruth MF, Wyman CE (1999) Cellulase for commodity products from cellulosic biomass. Curr Opin Biotech 10:358-364

7. Alani B, Zamani M, Motallebi M, Zarghami N, Mashayekhi M, Onsori H (2005) Purification of Polygalacturonase enzyme from Strain F58 of Fusarium oxysporum. Mol Cell Proteomics 4:285

8. Patel AK, Singhania RR, Sim SJ, Pandey A (2019) Thermostable cellulases: current status and perspectives. BioresourTechnol 279:385-392
9. Lynd LR, Weimer PJ, Van Zyl WH, Pretorius IS (2002) Microbial cellulose utilization: fundamentals and biotechnology. Microbiol Mol Biol Rev 66:506-577

10. Makky EA (2009) Avicelase production by a thermophilic Geobacillus stearothermophilus isolated from soil using sugarcane bagasse. World Acad Sci Eng Technol 57:87-92

11. Maleki M, Shahraki MF, Kavousi K, Ariaeenejad S, Salekdeh GH (2020) A novel thermostable cellulase cocktail enhances lignocellulosic bioconversion and biorefining in a broad range of $\mathrm{pH}$. Int J Biol Macromolec 154:349-360

12. Shah F, Jain D, Mitra M, Ram S, Gopal B, Bharadwaj SV, Tirkey S, Mishra S (2018) Sustainability studies of bacteria derived cellulase and its evaluation for wash performance analysis. Int J Biol Sci Appl 5:34-44

13. Brijwani K, Oberoi HS, Vadlani PV (2010) Production of a cellulolytic enzyme system in mixed-culture solid-state fermentation of soybean hulls supplemented with wheat bran. Process Biochem 45(1):120-128

14. Moorthy IMG, Baskar R (2013) Statistical modeling and optimization of alkaline protease production from a newly isolated alkalophilic Bacillus species BGS using response surface methodology and genetic algorithm. Prep Biochem Biotechnol 43(3):293-314

15. Box GE, Behnken DW (1960) Some new three level designs for the study of quantitative variables. Technometrics 2(4):455-475

16. Freire MG, Teles ARR, Rocha MMA, Schroder B, Neves CMSS, Carvalho PJ, Evtuguin DV, Santos LMNBF, Coutinho JAP (2011) Thermophysical characterization of ionic liquids able to dissolve biomass. J Chem Eng Data 56:4813-4822

17. De Coninck J, Bouquelet S, Dumortier V, Duyme F, VerdierDenantes I (2000) Industrial media and fermentation processes for improved growth and protease production by Tetrahymena thermophila BIII. J Ind Microbiol Biotechnol 24:285-290

18. Acharya A, Joshi DR, Shrestha K, Bhatta DR (2012) Isolation and screening of thermophilic cellulolytic bacteria from compost piles. Sci World 10:43-46

19. Ghose TK (1987) Measurement of cellulase activities. Pure Appl Chem 59:257-268

20. Poorakbar E, Saboury AA, Rad BL, Khoshnevisan K (2020) Immobilization of cellulase onto core-shell magnetic gold nanoparticles functionalized by aspartic acid and determination of its activity. The Protein J 39(4):328-336

21. Paudel YP, Qin W (2015) Characterization of novel cellulaseproducing bacteria isolated from rotting wood samples. Appl Biochem Biotechnol 177:1186-1198

22. Yin LJ, Huang PS, Lin HH (2010) Isolation of cellulase-producing bacteria and characterization of the cellulase from the isolated bacterium Cellulomonas sp. YJ5. J Agric Food Chem 58:9833-9837

23. Ray AK, Bairagi A, Ghosh KS, Sen SK (2007) Optimization of fermentation conditions for cellulase production by Bacillus subtilis CY5 and Bacillus circulans TP3 isolated from fish gut. Acta Ichthyol ET Piscat 37:47-53

24. Nasr SA, Abozaid AA, Hussein NA, AI-Salemi FA (2011) Cellulase production by local bacteria isolated from Taif in Saudi Arabia. J Agric Sci 19:163-170

25. Padilha QM, Carvalho LCT, Dias PVS, Grisi TCSL, da Silva FLH (2015) Production and characterization of thermophilic carboxymethyl cellulase synthesized by Bacillus sp. growing on sugarcane bagasse in submerged fermentation. Braz J Chem Eng 32(2015):35-42

26. Bose S, Armstrong DE, Petrich JW (2010) Enzyme-catalyzed hydrolysis of cellulose in ionic liquids: a green approach toward the production of biofuels. J Phys Chem B 114:8221-8227 
27. Constatinescu D, Herrmann C, Weingärtner H (2010) Patterns of protein unfolding and protein aggregation in ionic liquids. Phys Chem Chem Phys 12:1756-1763

28. Moniruzzaman M, Kamiya N, Goto M (2010) Activation and stabilization of enzymes in ionic liquids. Org Biomol Chem 8:2887-2899

29. Park S, Kazlauskas RJ (2003) Biocatalysis in ionic liquidsadvantages beyond green technology. Curr Opin Biotechnol 14:432-437

30. Zhao H, Olubajo O, Song Z, Sims AL, Person TE, Lawal RA, Holley LA (2006) Effect of kosmotropicity of ionic liquids on the enzyme stability in aqueous solutions. Bioorg Chem 34:15-25

31. van Rantwijk F, Sheldon RA (2007) Biocatalysis in ionic liquids. Chem Rev 107:2757-2785

32. Fukuchi S, Yoshimune K, Wakayama M, Moriguchi M, Nishikawa $\mathrm{K}$ (2003) Unique amino acid composition of proteins in halophilic bacteria. J Mol Biol 327:347-357

33. Hutcheon GW, Vasisht N, Bolhuis A (2005) Characterization of a highly stable a-amylase from the halophilic archaeon Haloarcula hispanica. Extremophiles 9:487-495

34. Lanyi JK (1974) Salt-dependent properties of proteins from extremely halophilic bacteria. Bacteriol Rev 38:272

35. Paul S, Bag SK, Das S, Harvill ET, Dutta C (2008) Molecular signature of hypersaline adaptation: insights from genome and proteome composition of halophilic prokaryotes. Genome Biol 9:R70

36. Ebel C, Costenaro L, Pascu M, Faou P, Kernel B, Proust-De Martin F, Zaccai G (2002) Solvent interactions of halophilic malate dehydrogenase. Biochem 41:13234-13244

37. Ebel C, Faou P, Kernel B, Zaccai G (1999) Relative role of anions and cations in the stabilization of halophilic malate dehydrogenase. Biochem 38:9039-9047

38. Mevarech M, Frolow F, Gloss LM (2002) Halophilic enzymes: proteins with a grain of salt. Biophys Chem 86:155-164

39. Tadeo X, López-Méndez B, Trigueros T, Laín A, Castaño D, Millet $O$ (2009) Structural basis for the aminoacid composition of proteins from halophilic archea. PLoS Biol 7(12):e1000257
40. Zaccai G, Cendrin F, Haik Y, Borochov N, Eisenberg H (1989) Stabilization of halophilic malate dehydrogenase. J Molec Biol 208:491-500

41. Lugani Y, Singla R, Sooch BS (2015) Optimization of cellulase production from newly isolated Bacillus sp. Y3. J Bioprocess Biotech $5: 1$

42. Das A, Bhattacharya $S$, Murali $L$ (2010) Production of cellulase from a thermophilic Bacillus sp. isolated from cow dung. Am Eurasian J Agric Environ Sci 8:685-691

43. Sreedevi S, Sajith S, Benjamin S (2013) Cellulase producing bacteria from the wood-yards on Kallai river bank. Adv Microbiol 3:326-332

44. Acharya S, Chaudhary A (2011) Effect of nutritional and environmental factors on cellulases activity by thermophilic bacteria isolated from hot spring. J Sci Ind Res 70:142-148

45. Shankar T, Isaiarasu L (2011) Cellulase production by Bacillus pumilus EWBCM1 under varying cultural conditions. J Sci Res 8:40-45

46. Ishihara M, Matsunaga M, Hayashi N, Tišler V (2002) Utilization of $D$-xylose as carbon source for production of bacterial cellulose. Enzyme Microb Tech 31:986-991

47. Oikawa T, Morino T, Ameyama M (1995) Production of cellulose from D-arabitol by Acetobacter xylinum KU-1. Biosci Biotechnol Biochem 59:15641565

48. Ramana KV, Tomar A, Singh L (2000) Effect of various carbon and nitrogen sources on cellulose synthesis by Acetobacter xylinum. World J Microbiol Biotechnol 16:245-248

49. Ariffin $\mathrm{H}$, Abdullah $\mathrm{N}$, Umi Kalsom MS, Shirai Y, Hassan MA (2006) Production and characterization of cellulase by Bacillus pumilus EB3. Int J Eng Technol 3:47-53

50. Pandey A, Selvakumar P, Soccol CR, Nigam P (1999) Solid-state fermentation for the production of industrial enzymes. Curr Sci $77: 149-152$

Publisher's Note Springer Nature remains neutral with regard to jurisdictional claims in published maps and institutional affiliations. 